TEACHING : Jurnal Inovasi Keguruan dan IImu Pendidikan

Vol. 1. No. 4 Desember 2021 e-ISSN : 2775-7188 | p-ISSN : 2775-717X

\title{
UPAYA MENINGKATKAN KEPERCAYAAN DIRI MELALUI LAYANAN KONSELING INDIVIDUAL SISWA KELS IX.A SMPN 1 LENEK MASA COVID-19 TAHUN PELAJARAN 2021/2022
}

\author{
AINI \\ SMPN 1 Lenek \\ Email : hjaini2022@gmail.com
}

\begin{abstract}
ABSTRAK
Tujuan Penelitian ini yaitu kepercayaan diri siswa kelas IX-A SMPN 1 Lenek dapat meningkat melalui layanan konseling individual masa covid-19 tahun pelajaran 2021/2022. Jenis penelitian ini yaitu penelitian tindakan kelas (PTK). Tahap-tahapan dalam penelitian ini yaitu: (1) rancangan tindakan; (2) pelaksanaan tindakan; (3) observasi; dan (4) refleksi. Subjek penelitian ditentukan dengan teknik porposive sampling. Subjek penelitian yaitu kelas IX-A SMPN 1 Lenek. Teknik pengumpulan data yang digunakan dalam penelitian ini yaitu teknik non-tes. Instrumen yang digunakan untuk mengukur tingkat kepercayaan diri siswa berupa angket keprecayaan diri siswa. Instrumen yang digunakan untuk mengukur keterlaksanaan layanan konseling individual yaitu lembar keterlaksanaan layanan konseling individu. Analisis data menggunakan analisis deskriptif kuantitatif. Hasil penelitian menunjukan bahwa kepercayaan diri siswa kelas IX-A SMPN 1 Lenek dapat meningkat melalui layanan konseling individual masa covid-19 2021/2022 dengan tingkat keterlaksanaan layanan konseling individual pada sikus I maupun siklus II yaitu sebesar $90 \%$.
\end{abstract}

Kata Kunci: Kepercayaan Diri, Layanan Konseling Individual

ABSTRACT

The purpose of this study is that the self-confidence of grade IX-A SMPN 1 Lenek students can increase through individual counseling services during the COVID-19 period of the 2021/2022 school year. This type of research is classroom action research (CAR). The stages in this research are: (1) plan; (2) actions; (3) observation; and (4) reflection. Research subjects were determined by using a proportional sampling technique. The research subject is class IX-A SMPN 1 Lenek. Data collection techniques used in this study are non-test and observation techniques. The instrument used to measure the level of student confidence is a student selfconfidence questionnaire. The instrument used to measure the implementation of individual counseling services is the individual counseling service implementation sheet. Data analysis used quantitative descriptive analysis. The results showed that the self-confidence of class IXA students of SMPN 1 Lenek could increase through individual counseling services for the COVID-19 2021/2022 period with the level of implementation of individual counseling services in Cycle I and Cycle II, which was $90 \%$.

Keywords: Confidence, Individual Counseling Service

\section{PENDAHULUAN}

Kepercayaan diri merupakan modal dasar bagi individu untuk melakukan kegiatan dalam kehidupan sehari-hari. Kepercayaan diri seorang individu dapat terbantu dalam melakukan hubungan sosial dengan sesama temannya. Kepercayaan diri sebagai suatu dimensi yang bersifat evaluasi yang dapat menggambarkan keseluruhan diri seseorang (Santrock, 2003: 336). Kepercayaan diri yang tinggi menggambarkan individu memiliki harga diri. Merasa diri berharga akan mempengaruhi penampilan individu dalam berinteraksi dengan lingkungan sosialnya.

Salah satu aspek kepribadian yang menunjukan sumber daya manusia yang berkualitas adalah tingkat kepercayaan diri. Kepercayaan diri adalah karakteristik pribadi seseorang yang di dalamnya terdapat keyakinan akan kemampuan diri dan mampu mengembangkan serta mengolah dirinya sebagai pribadi yang mampu menanggulangi suatu masalah dengan situasi 
terbaik (Afiatin \& Andayani dalam Ghufron dan Rini, 2010: 34). Orang yang percaya diri akan memiliki konsep diri yang positif dan akan terus mengembangkan sikap positif terhadap dirinya-sendiri maupun lingkungan. De Angelis (2002: 5) juga menjelaskan bahwa kepercayaan diri merupakan sesuatu yang mampu menyalurkan apa yang seorang individu ketahui dan segala yang dikerjakan. Kepercayaan diri sejati bukan tumbuh dari tiadanya rasa takut dalam diri seorang individu, namun tumbuh dari keyakinan untuk terus melakukan walaupun ada ketakutan dalam diri. Dalam hubungannya dengan individu lain kepercayaan diri merupakan pendukung utama untuk dapat mengungkapkan pemikiran walaupun ada rasa takut yang mengganggu.

Selain itu, Al-Hebaish (2012:64) menyatakan kepercayaan diri menentukan keberhasilan siswa dalam pembelajaran dan berinteraksi dengan lingkungannya. Sejalan dengan itu, Yulidar, Y., \& Khairani, K. (2018: 68) juga menyatakan bahwa kepercayaan diri merupakan aspek kepribadian yang penting pada diri individu. Tanpa adanya kepercayaan diri, individu akan banyak mendapat masalah dalam kehidupannya. Dengan adanya kepercayaan diri, individu dapat dan terdorong untuk mengaktualisasikan semua potensi diri. Demikian pentingnya kepercayaan diri dalam kehidupan, maka diperlukan perhatian dan usaha untuk membantu dan meningkatkan kepercayaan diri siswa.

Fakta di lapangan menunjukkan bahwa siswa sering terlambat mengumpulkan tugas yang diberikan oleh guru; siswa sering kesulitan dalam menjawab pertanyaan yang diberikan oleh guru; dan siswa kurang berminat dalam mengikuti kegiatan praktik di lapangan. Permasalahan yang telah diuraikan tersebut tentunya harus mendapatkan penanganan yang komprehensif. Bimbingan dan konseling di sekolah merupakan salah satu sarana dalam membantu memecahkan permasalahan peserta didik salah satunya yaitu permasalahan kepercayaan diri rendah. Bimbingan dan konseling memiliki peran yang sangat penting untuk dapat membantu terciptanya tujuan pendidikan itu sendiri.

Layanan konseling individual sebagai salah satu bentuk layanan dalam bidang bimbingan dan konseling yang bersifat responsif. Pelayanan responsif merupakan pemberian bantuan kepada konseli yang menghadapi kebutuhan dan masalah yang memerlukan pertolongan dengan segera, sebab jika tidak segera dibantu dapat menimbulkan gangguan dalam proses pencapaian tugas-tugas perkembangan. Dapat disimpulkan bahwa konseling individual merupakan salah satu kegiatan yang dilaksanakan konselor dalam usaha membantu siswa mengentaskan masalah yang dialami melalui suatu bentuk hubungan pribadi yang khusus disertai kepercayaan agar konseli dapat mencapai pemahaman tentang diri dan masalahnya. Melalui konseling individual konseli akan memahami kondisi dirinya sendiri beserta lingkunganya.

Konseling individu juga akan membantu konseli menstrukturkan kembali masalahnya dan menyadari life style, serta mengurangi penilaian negatif terhadap dirinya sendiri serta perasaan-perasaan inferioritasnya (Prayitno, 2005: 288). Kemudian membantu dalam mengoreksi presepsinya terhadap lingkungan, agar konseli bisa mengarahkan tingkah laku serta mengembangkan kembali minat sosialnya. Selain itu, konseling individual adalah bantuan yang diberikan oleh konselor kepada seorang siswa dengan tujuan berkembangnya potensi siswa, mampu mengatasi masalah sendiri, dan dapat menyesuaikan diri secara positif (Willis, 2013). Konseling individu dianggap sebagai upaya layanan yang paling utama dalam pelaksanaan fungsi pengentasan masalah klien. Tanggung jawab konselor dalam proses konseling adalah mendorong untuk mengembangkan potensi klien, agar dia mampu bekerja efektif, produktif, dan menjadi manusia mandiri.

Sebuah hasil penelitian menunjukkan kepuasan siswa terhadap layanan konseling individual secara umum berada pada klasifikasi sedang atau cukup puas (Amalia, R. F., Badrujaman, A., \& Tjalla, A., 2016). Sejalan dengan itu, hasil penelitian lainnya Daroni dkk. (2018) juga menunjukkan layanan konseling individual dapat membuat klien memiliki kepercayaan diri sebagai orang tua yang memiliki anak autis. Selain itu, hasil penelitian lainnya (Nawas, F., 2021) menunjukkan bahwa perubahan pada diri siswa yang memiliki kepercayaan 
diri rendah setelah mengikuti layanan konseling yaitu terjadi peningkatan kepercayaan diri rendah secara signifikan.

\section{METODE PENELITIAN}

Jenis penelitian ini yaitu penelitian tindakan kelas. Penelitian tindakan kelas adalah suatu pencermatan terhadap kegiatan belajar berupa sebuah tindakan, yang sengaja dimunculkan dan terjadi dalam sebuah kelas secara bersamaan (Suharsimi A., 2006: 9). Dalam penelitian ini menggunakan desain penelitian tindakan kelas yang dikembangkan oleh Prof. Suharsimi Arikunto. Adapun gambar desain penelitian tindakan kelas yang digunakan dalam penelitian ini sebagai berikut (Suharsimi A., 2006: 16).:

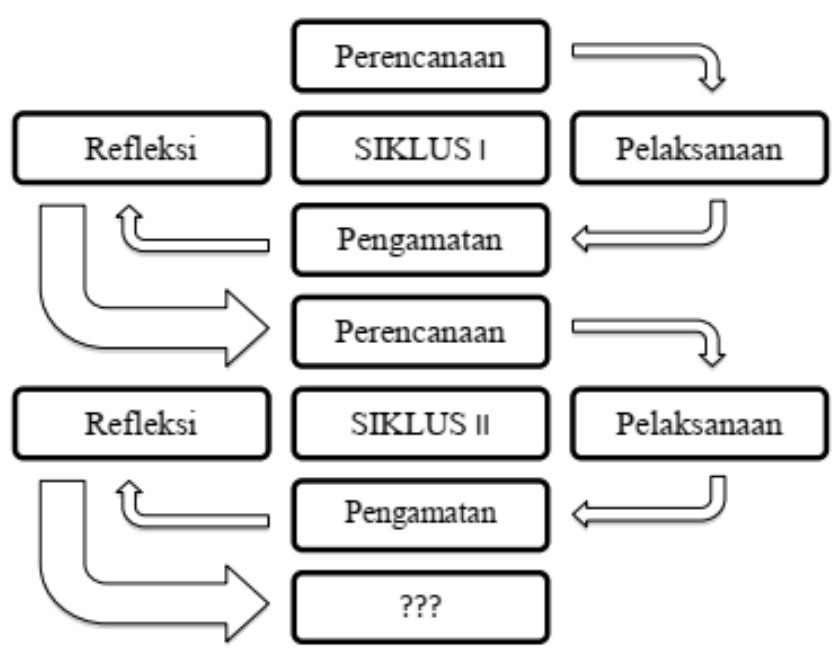

Gambar 1. Proses Penelitian Tindakan Kelas

Berdasarkan gambar 1 dapat disimpulkan bahwa proses penelitian terdiri dari: (1) perencanaan; (2) tindakan; (3) observasi; dan (4) refleksi. Penelitian akan terus berlanjut apabila dalam dalam siklus pertama belum mendapatkan hasil yang diinginkan, tetapi dengan melakukan perbaikan dalam tahap perencanaan.

Teknik yang digunakan dalam pemelihan subjek penelitian yaitu purposive sampling. Dari keseluruhan 30 siswa kelas IX.A SMP Negeri 1 Lenek, dipilih 3 siswa. Pertimbangan yang digunakan dalam menentukan subyek penelitian tersebut berdasarkan:

1) Senang tidak masuk Sekolah.

2) Sering mengantuk saat mengikuti roses pembelajaran di kelas.

3) Jarang mengerjakan tugas yang diberikan oleh guru mata pelajaran.

Berdasarkan sumber data yang digunakan dalam penelitian ini, maka teknik pengumpulan data yang digunakan antara lain:

1) Non-Tes

Menurut Arikunto (2002, hlm. 26) "teknik non tes meliputi skala bertingkat, kuisioner, daftar cocok, wawancara, pengamatan, dan riwayat hidup". Pengumpulan data dengan teknik non tes adalah pelaksanaan penilaian dengan menyajikan serangkaian pertanyaan yang harus dijawab dengan jujur atau apa adanya oleh responden. Metode penilaian non-tes dilaksanakan melalui wawancara, observasi, angket dan dokumentasi. Bentuk instrumen yang digunakan dengan teknik non-tes, yaitu (1) angket ; dan (2) lembar observasi.

2) Dokumentasi

Dokumentasi yaitu teknik pengumpulan data dengan menyelidiki benda-benda tertulis seperti buku, majalah, dokumen, peraturan, notulen rapat, dan catatan harian (Suharsimi, 2013: 201).

Instrumen-instrumen yang digunakan dalam penelitian ini antara lain: 
1) Angket

Angket merupakan jenis instrumen di dalam teknik komunikasi tidak langsung, yaitu data yang dihimpun bersifat informatif dengan atau tanpa pendapat, buah pikiran, dan penilaian. Dalam penelitian ini angket yang digunakan adalah jenis angket tertutup dengan bentuk rating scale, yaitu sebuah pernyataan yang diikuti oleh kolom-kolom yang menunjukkan kriteria tingkat jawaban. Dimana responden harus memilih salah satu jawaban yang menurut pendapatnya/keadaannya paling tepat (benar). Angket ini digunakan untuk mengetahui peningkatan kepercayaan diri siswa melalui layanan konseling individual.

2) Observasi

Observasi dilakukan untuk mengamati pelaksanaan pemberian tindakan berupa layanan konseling individual yang diberikan oleh guru kepada siswa. Lembar observasi disusun berdasarkan indikator-indikator yang ada pada definisi konseptual layanan konseling individual. Observasi dilakukan dengan bantuan seoarang observer (pengamat).

Validitas instrumen yang digunakan dalam penelitian ini yaitu bukti validitas isi. Validitas isi suatu instrumen ditentukan menggunakan kesepakatan ahli. Hal ini dikarenakan instrumen pengukuran, misalnya berupa tes atau angket dibuktikan valid jika ahli (expert) meyakini bahwa instrumen tersebut mengukur penguasaan kemampuan yang didefinisikan dalam domain ataupun juga konstruk psikologi yang diukur (Retnawati, 2015: 18). Dalam penelitian ini, instrumen penelitian yang akan dibuktikan kevalidannya yaitu angket kepercayaan diri siswa. Selanjutnya, untuk menghitung hasil kesepakatan ahli pada angket kepercayaan diri siswa yang telah dinilai menggunakan indeks Gregory.

Pada penelitian ini, estimasi reliabelitas instrumen angket kepercayaan diri siswa dihitung menggunakan rumus Alpha dari Cronbach. Rumus Alpha digunakan untuk mengistemasi reliabelitas instrumen yang skornya bukan hanya 1 dan 0 , namun juka skala politomus, misalnya angket yang menggunakan skala Likert (Retnawati, 2015: 91). Rumus Alpha sebagai berikut:

$$
\alpha=\left(\frac{k}{k-1}\right)\left(1-\frac{\sum \sigma_{i}^{2}}{\sigma_{t}^{2}}\right)
$$

Dengan:

$\alpha=$ koefisien reliabelitas instrumen

$k=$ banyaknya butir pertanyaan dalam instrumen

$\sum \sigma_{i}^{2}=$ jumlah varians butir instrumen

$\sigma_{t}^{2}=$ varians skor total

Teknik analisis yang digunakan dalam penelitian adalah analisis deskriptif kuantitatif. Analisis kuantitatif digunakan untuk meneliti populasi atau sampel tertentu, teknik pengambilan sampel pada umumnya dilakukan secara random, pengumpulan data menggunakan instrumen penelitian, dengan hasil berupa data statistik (Sugiyono, 2007:13).

Data yang diperoleh peneliti dikumpulkan dan dianalisis untuk mengetahui perkembangan kepercayaan diri peserta didik pada tiap siklus. Dari hasil penelitian dapat dihitung dengan persentase. Adapun rumus yang digunakan untuk menghitung rata-rata persentase sebagai berikut (Sujdiono, 2010:43):

Keterangan:

$$
P=\frac{f}{N} \times 100 \%
$$

$\mathrm{f}$ : Frekuensi yang sedang dicari persentasenya

$\mathrm{N}$ : Number of class (jumlah frekuensi/banyaknya individu)

$\mathrm{P}$ : Angka persentase

Penelitian ini dikatakan berhasil jika terjadi peningkatan kepercayaan diri siswa dari siklus I ke siklus II yang diukur melalui angket kepercayaan diri siswa dengan persentase hasil observasi keterlaksanaan tindakan mencapai $80 \%$. 


\section{HASIL DAN PEMBAHASAN}

Untuk memudahkan pemahaman dan pembacaan, hasil penelitian dideskripsikan terlebih dahulu, dilanjutkan bagian pembahasan. Subjudul hasil dan subjudul pembahasan disajikan terpisah. Bagian ini harus menjadi bagian yang paling banyak, minimum $60 \%$ dari keseluruhan badan artikel.

Hasil Penelitian

Hasil pelaksanaan siklus I dan siklus II diuraikan sebagai berikut:

\section{Deskripsi Siklus I}

Hasil pelaksanaan siklus I disajikan pada tabel sebagai berikut:

Tabel 1. Hasil Pelaksanaan Siklus I

Siklus I Bentuk Kegiatan

\begin{tabular}{|c|c|}
\hline Perencanaan & $\begin{array}{l}\text { Menyusun rencana layanan konseling individual. } \\
\text { Menyiapkan rencana layanan konseling. } \\
\text { Denyiapkan lembar observasi layanan konseling individual } \\
\text { Denyiapkan seorang observar } \\
\text { Peneliti menyusun jadwal layanan konseling individual siklus II } \\
\text { Peneliti memberitahukan kepada siswa tentang jadwal layanan konseling } \\
\text { individual siklus II. }\end{array}$ \\
\hline Tindakan & $\begin{array}{l}\text { Memberitahukan kepada siswa yang akan diberikan layanan konseling } \\
\text { individu dan juga observer mengenai jadwal layanan konseling individu } \\
\text { siklus I. } \\
\text { Menyelenggarakan layanan konseling individual dengan tahap-tahap } \\
\text { pelaksanaannya sebagai berikut: } \\
\checkmark \text { Tahap Awal Konseling: } \\
\text { - Peneliti membuka layanan konseling individual dengan } \\
\text { mengucapkan salam setelah semua siswa yang mengikuti layanan } \\
\text { konseling hadir dan siap. } \\
\text { - Dilanjutkan dengan berdoa dan menanyakan kabar siswa. } \\
\text { - Peneliti menjelaskan tentang pengertian, tujuan, dan asas-asas yang } \\
\text { digunakan dalam layanan konseling individual. } \\
\checkmark \text { Tahap Pertengahan Konseling: } \\
\text { - Peneliti menjelaskan secara singkat lagi mengenai kegiatan layanan } \\
\text { konsleing individual. } \\
\text { - Menanyakan kesiapan para anggota kelompok untuk masuk pada } \\
\text { selanjutnya yaitu tahap kegiatan. } \\
\text { - Peneliti memberikan beberapa pertanyaan kepada siswa. } \\
\checkmark \text { Tahap Akhir Konseling: } \\
\text { - Menyampaikan hasil kesimpulan pada siswa yang mengikuti layanan } \\
\text { konseling. } \\
\text { - Peneliti menutup layanan konseling individual dengan } \\
\text { mengucapkan salam. }\end{array}$ \\
\hline
\end{tabular}

Observasi Hasil observasi keterlaksanaan layanan konseling individual bahwa keterlaksanaa layanan konseling individual berjalan dengan tingkat keterlaksana sebesar $90 \%$.

Refleksi Dalam refleksi ini telah dilakukan diskusi antara guru dan oberver. Hasil refleksi pada taha ini yaitu keterlaksanaan layanan konseling individual diperoleh tingkat keterlaksanaan layanan konseling individual sebesar $90 \%$. 
Berikut disajikan pelaksanaan kegiatan tindakan layanan konseling individual pada siklus I:
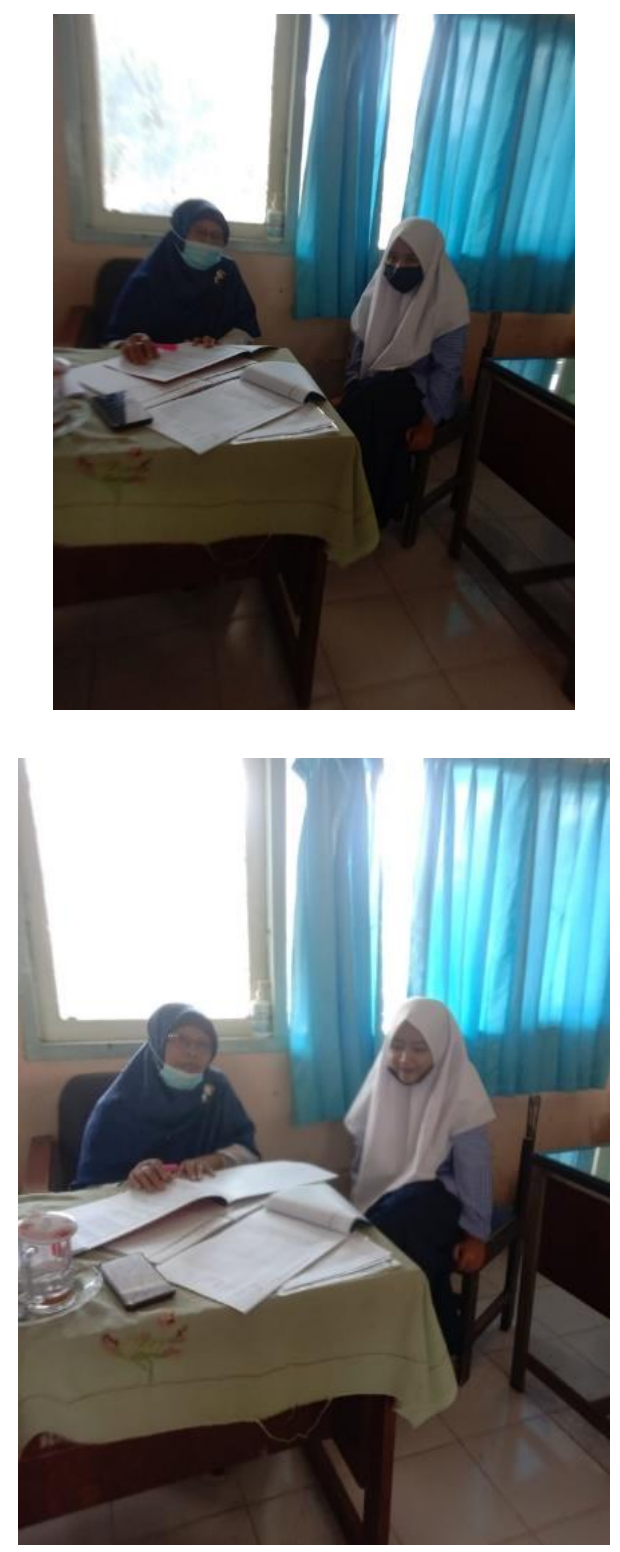

Gambar 2. Foto Pelaksanaan Layanan Konseling Individual

Selanjutnya, hasil pengukuran tingkat kepercayaan diri siswa diperoleh sebagaimana disajikan dalam tabel sebagai berikut:

Tabel 2. Hasil Pengukuran Tingkat Kepercayaan Diri Siswa pada Siklus I

$$
\text { No. }
$$

Nama

Jumlah Skor

Kategori

\begin{tabular}{llll}
\hline 1 & Siswa 01 & 63 & Sedang \\
\hline 2 & Siswa 02 & 61 & Sedang \\
\hline 3 & Siswa 03 & 60 & Sedang \\
\hline
\end{tabular}

Deskripsi Siklus II

Hasil pelaksanaan siklus II disajikan pada tabel sebagai berikut:

Tabel 3. Hasil Pelaksanaan Siklus I

Siklus I

Bentuk Kegiatan

Perencanaan $>$ Menyusun rencana layanan konseling individual.

Menyiapkan rencana layanan konseling.

Menyiapkan lembar observasi layanan konseling individual 


\begin{tabular}{|c|c|}
\hline & $\begin{array}{l}>\text { Menyiapkan seorang observar } \\
>\text { Peneliti menyusun jadwal layanan konseling individual siklus II } \\
\text { Peneliti memberitahukan kepada siswa tentang jadwal layanan konseling } \\
\text { individual siklus II. }\end{array}$ \\
\hline Tindakan & $\begin{array}{l}\text { Memberitahukan kepada siswa yang akan diberikan layanan konseling } \\
\text { individu dan juga observer mengenai jadwal layanan konseling individu } \\
\text { siklus I. } \\
\text { Menyelenggarakan layanan konseling individual dengan tahap-tahap } \\
\text { pelaksanaannya sebagai berikut: } \\
\checkmark \text { Tahap Awal Konseling: } \\
\text { - Peneliti membuka layanan konseling individual dengan } \\
\text { mengucapkan salam setelah semua siswa yang mengikuti layanan } \\
\text { konseling hadir dan siap. } \\
\text { - Dilanjutkan dengan berdoa dan menanyakan kabar siswa. } \\
\text { - Peneliti menjelaskan tentang pengertian, tujuan, dan asas-asas yang } \\
\text { digunakan dalam layanan konseling individual. } \\
\checkmark \text { Tahap Pertengahan Konseling: } \\
\text { - Peneliti menjelaskan secara singkat lagi mengenai kegiatan layanan } \\
\text { konsleing individual. } \\
\text { - Menanyakan kesiapan para anggota kelompok untuk masuk pada } \\
\text { selanjutnya yaitu tahap kegiatan. } \\
\text { - Peneliti memberikan beberapa pertanyaan kepada siswa. } \\
\checkmark \text { Tahap Akhir Konseling: } \\
\text { - Menyampaikan hasil kesimpulan pada siswa yang mengikuti layanan } \\
\text { konseling. } \\
\text { - Peneliti menutup layanan konseling individual dengan } \\
\text { mengucapkan salam. }\end{array}$ \\
\hline
\end{tabular}

Observasi Hasil observasi keterlaksanaan layanan konseling individual bahwa keterlaksanaa layanan konseling individual berjalan dengan tingkat keterlaksana sebesar $90 \%$.

Refleksi Dalam refleksi ini telah dilakukan diskusi antara guru dan oberver. Hasil refleksi pada taha ini yaitu keterlaksanaan layanan konseling individual diperoleh tingkat keterlaksanaan layanan konseling individual sebesar $90 \%$.

Selanjutnya, hasil pengukuran tingkat kepercayaan diri siswa diperoleh sebagaimana disajikan dalam tabel sebagai berikut:

\section{Tabel 4. Hasil Pengukuran Tingkat Kepercayaan Diri Siswa pada Siklus II No. Nama Jumlah Skor Kategori}

\begin{tabular}{llll}
\hline 1 & Siswa 01 & 73 & Tinggi \\
\hline 2 & Siswa 02 & 75 & Tinggi \\
\hline 3 & Siswa 03 & 72 & Tinggi \\
\hline
\end{tabular}

\section{Pembahasan}

Berdasarkan hasil penelitian yang telah diuraikan pada sub-bab sebelumnya, diperoleh hasil pengukuran kepercayaan diri pada mata pelajaran-mata pelajaran yang diikuti oleh subjek penelitian yang disajikan pada tabel sebagai berikut: 
TEACHING : Jurnal Inovasi Keguruan dan IImu Pendidikan

Vol. 1. No. 4 Desember 2021 e-ISSN : 2775-7188 | p-ISSN : 2775-717X

Tabel 5. Hasil Pengukuran Tingkat Kepercayaan Diri Siswa pada Siklus I dan Siklus II

\begin{tabular}{cccccc} 
No. & Nama & \multicolumn{2}{c}{ Siklus I } & \multicolumn{2}{c}{ Siklus II } \\
\cline { 3 - 6 } & & $\begin{array}{c}\text { Jumlah } \\
\text { Skor }\end{array}$ & Kategori & $\begin{array}{c}\text { Jumlah } \\
\text { Skor }\end{array}$ & Kategori \\
\hline 1 & Siswa 01 & 63 & Sedang & 73 & Tinggi \\
\hline 2 & Siswa 02 & 61 & Sedang & 75 & Tinggi \\
\hline 3 & Siswa 03 & 60 & Sedang & 72 & Tinggi \\
\hline
\end{tabular}

Pada siklus I, ketiga siswa memperoleh skor berturut-turut, yaitu 63, 61, dan 60 yang ketiganya termasuk ke dalam kategori sedang. Sementara itu, pada siklus II, ketiga siswa mempeorleh skor berturut-turut, yaitu 73, 75 dan 72. yang ketiganya termasuk ke dalam kategori tinggi. Adapun tingkat keterlaksanaan layanan konseling individual baik siklus I maupun siklus II telah terlaksana sesuai harapan, yaitu kedua siklus masing-masing terlaksana sebesar $90 \%$.

Berikut ini disajikan hasil pengukuran tingkat kepercayaan diri siswa pada siklus I dan siklus II pada grafik 1 .

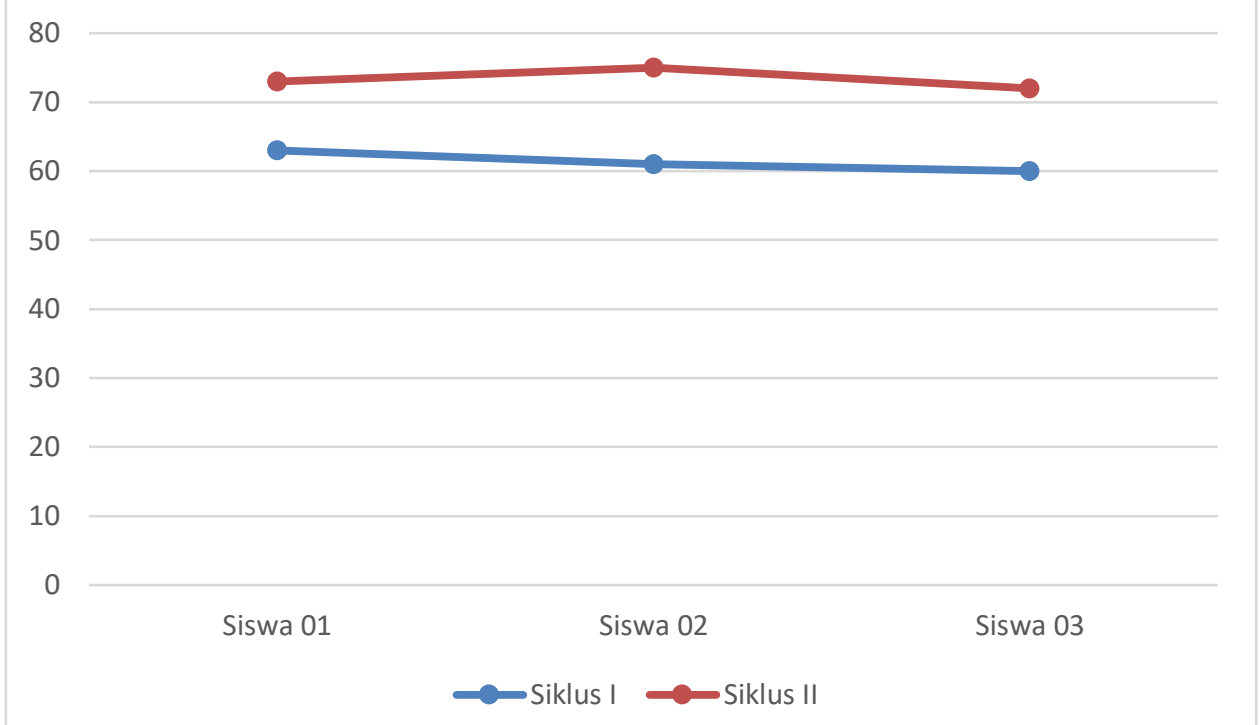

Gambar 3. Grafik Hasil Pengukuran Tingkat Kepercayaan Diri Siswa pada Siklus I dan Siklus II

Peningkatan skor kepercayaan diri siswa didukung oleh beberapa hal. Secara teknis, kolaborasi yang baik antara peneliti, observer, dan siswa memberikan pengaruh positif terhadap lancarnya pelaksanaan layanan konsleing individual. Antusiasme siswa yang tinggi dalam mengikuti layanan konseling individual menjadikan layanan konseling individual berjalan lancar. Materi layanan konseling individual yang diberikan oleh peniliti membuat siswa memahami tujuan dari layanan konseling individual. Faktor tersebut secara tidak langsung berpengaruh terhadap hasil tindakan yang bertujuan untuk meningkatkan kepercayaan diri siswa.

Melalui refleksi yang dilakukan peneliti dan observer, siswa mengaku merasa senang mengikuti kegiatan layanan konseling ini, karena tidak hanya mendengarkan ceramah saja, namun juga langsung belajar memecahkan masalah dan praktik melakukan apa yang diberikan. Dari refleksi diketahui bahwa melalui layanan konseling individual ini, siswa tidak hanya belajar teori untuk meningkatkan kemampuan kognitif, namun juga secara afektif terlibat aktif berpartisipasi dalam layanan konseling ini.

Secara teoritik, layanan konseling individual dianggap sebagai upaya layanan yang paling utama dalam pelaksanaan fungsi pengentasan masalah klien. Apabila layanan konseling telah memberikan jasanya, maka masalah klien akan teratasi secara efektif dan upaya-upaya bimbingan lainnya tinggal mengikuti atau berperan sebagai pendamping (Prayitno \& Amti, 
2015). Selain itu, hasil penelitian ini juga didukung oleh hasil penelitian Nawas F. yang menunjukkan perubahan pada diri siswa yang memiliki kepercayaan diri rendah setelah mengikuti layanan konseling yaitu terjadi peningkatan kepercayaan diri rendah secara signifikan (Nawas F., 2021) Sejalan dengan itu, hasil penelitian Daroni, G. A. dkk. menunjukkan hasil dari konseling individu menggunakan teknik REBT orang tua sadar bahwa anaknya membutuhkan dukungan dari orang tuanya, karena salah satu keberhasilan terapi untuk anak autis adalah dukungan dari orang tuanya (Daroni, G. A., et. al., 2018).

\section{KESIMPULAN}

Berdasarkan hasil penelitian dan pembahasan dapat disimpulkan bahwa kepercayaan diri siswa kelas IX-A SMPN 1 Lenek dapat meningkat melalui layanan konseling individual masa covid-19 2021/2022 dengan tingkat keterlaksanaan layanan konseling individual pada sikus I maupun siklus II yaitu sebesar $90 \%$. Hal ini ditunjukkan oleh adanya peningkatan tingkat kepercayaan diri siswa dari siklus I ke siklus II. Hal ini dibuktikan dengan perolehan skor kepercayaan diri ketiga siswa pada siklus I dan siklus II. Pada siklus I, ketiga siswa memperoleh skor berturut-turut, yaitu 100, 98, dan 98 yang ketiganya termasuk ke dalam kategori sedang. Sementara itu, pada siklus II, ketiga siswa mempeorleh skor berturut-turut, yaitu 106, 106, dan 104 yang ketiganya termasuk ke dalam kategori tinggi.

\section{DAFTAR PUSTAKA}

Al-Hebaish, Mohammad Safaa. (2012). The Correlation between General Self Confidence and Academic Achievement in the Oral Presentation Course. [Online]. Diakses dari: www.academypublication.com/issues/past/tpls/ vol02/01/08.pdf

Amalia, R. F., Badrujaman, A., \& Tjalla, A. (2016). KEPUASAN SISWA TERHADAP LAYANAN KONSELING INDIVIDUAL (Survei pada siswa kelas VIII di SMP Negeri se-Kecamatan Matraman, Jakarta Timur). INSIGHT: Jurnal Bimbingan Konseling, 5(1), 87-93. Doi: https://doi.org/10.21009/INSIGHT.051.13

Angelis, De Barbara, (2003). Comfidence Sumber Sukses Dan Kemandirian. Jakarta: Gramedia Pustaka Utama.

Arikunto, S. (2006). Penelitian Tindakan Kelas. Jakarta: Bumi Aksara.

Daroni, G. A., Yusuf, M., Salim, A., Gunarhadi, G., \& Legowo, E. (2018). Konseling individu untuk meningkatkan kepercayaan diri orang tua yang memiliki anak autis. Counsellia: Jurnal Bimbingan dan Konseling, 8(2), 100-113. htp://ejournal.unipma.ac.id/index.php/JBK/article/view/2904/1903.

Ghufron, M. N., \& Risnawita S, R. (2010). Teori-Teori Psikologi. Yogyakarta: Ar-Ruzz Media.

Nawas, F. (2021). Layanan Konseling Individu Pada Peningkatan Kepercayaan Diri Siswa (Doctoral dissertation, UNIVERSITAS MUHAMMADIYAH PALOPO). http://repository.umpalopo.ac.id/1131/.

Retnawati, Heri. (2016). Validitas Reliabilitas dan Karakteristik Butir: (Panduan Untuk Peneliti, Mahasiswa, Dan Psikometrian). Yogyakarta: Parama Publishing

Santrock, J. W. (2003). Adolescence: Perkembangan Remaja (Edisi keenam). Jakarta: Erlangga.

Sofyan, S. W. (2010). Remaja dan masalahnya. Bandung: CV Alfabeta.

Sugiyono. (2012). Metode Penelitian Kuantitatif, Kualitatif, Dan Kombinasi (Mixed Methods). Bandung: Alfabeta.

Yulidar, Y., \& Khairani, K. (2018). Meningkatkan Kepercayaan Diri Siswa dan Peran Konselor Sekolah. In International Conferences on Educational, Social Sciences and Technology. Fakultas Ilmu Pendidikan UNP. https://scholar.google.com/scholar?hl=en\&as_sdt=0\%2C5\&q=Yulidar\%2C+Y.\%2C $+\% 26+$ Khairani\%2C+K.+\%282018\%29.+Meningkatkan+Kepercayaan+Diri+Siswa + dan+Peran + Konselor + Sekolah\&btnG $=$ 